\title{
Gambaran Sebab Kematian pada Kasus Kematian Tidak Wajar yang Diautopsi di RS Bhayangkara Tingkat III Manado dan RSUP Prof. Dr. R. D. Kandou Manado Tahun 2017-2018
}

\author{
Charissa P. Ango, ${ }^{1}$ Djemi Tomuka, ${ }^{2}$ Erwin Kristanto ${ }^{2}$
}

${ }^{1}$ Program Studi Pendidikan Dokter Fakultas Kedokteran Universitas Sam Ratulangi Manado

${ }^{2}$ Bagian Ilmu Kedokteran Forensik dan Medikolegal Fakultas Kedokteran Universitas Sam Ratulangi Manado / RSUP Prof. Dr. R. D. Kandou

Email: charissaango99@gmail.com

\begin{abstract}
Unnatural deaths are not caused by diseases but by others such as accidents, killings, and suicide. The death of someone which is suspected unnaturally, needs to be found out with certainty about the cause of death through an autopsy by a forensic doctor. This study was aimed to obtain the causes of unnatural death cases autopsied at RS Bhayangkara Tingkat III Manado and Prof. Dr. R. D. Kandou Hospital Manado in 2017-2018. This was a retrospective and descriptive study using Visum et Repertum data. The results showed 77 cases of unnatural deaths. As many as 45 cases were autopsied in 2017 and 32 cases in 2018. Most victims were male (68 cases), aged 17-25 years (late adolescence; 18 cases). The most common cause of death was sharp violence (45 cases). In conclusion, most autopsy cases of unnatural deaths were performed on males, aged 17-25 years (late adolescence), and sharp violence as the cause of death.
\end{abstract}

Keywords: unnatural death, cause of death, autopsy

\begin{abstract}
Abstrak: Kematian tidak wajar adalah kematian yang tidak disebabkan oleh penyakit, seperti kecelakaan, pembunuhan dan bunuh diri. Kematian seseorang yang diduga tidak wajar, perlu dicari tahu secara pasti penyebab kematiannya melalui autopsi oleh dokter forensik. Penelitian ini bertujuan untuk mengetahui gambaran sebab kematian pada kasus kematian tidak wajar yang diautopsi di RS Bhayangkara Manado Tingkat III dan RSUP Prof. Dr. R. D. Kandou Manado tahun 2017-2018. Jenis penelitian ialah deskriptif retrospektif menggunakan data hasil Visum et Repertum. Hasil penelitian mendapatkan 77 kasus kematian tidak wajar yang diautopsi, yaitu pada tahun 2017 sebanyak 45 kasus dan pada tahun 2018 sebanyak 32 kasus. Jenis kelamin laki-laki lebih banyak daripada perempuan (68 kasus vs 9 kasus). Usia terbanyak ialah 17-25 tahun (masa remaja akhir) sebanyak 18 kasus. Penyebab kematian terbanyak ialah kekerasan tajam sebanyak 45 kasus. Simpulan penelitian ini ialah sebagian besar kasus kematian tidak wajar yang diautopsi dilakukan pada usia 17-25 tahun (masa remaja akhir), jenis kelamin laki-laki, dengan sebab kematian kekerasan tajam.
\end{abstract}

Kata kunci: kematian tidak wajar, sebab kematian, autopsi

\section{PENDAHULUAN}

Kematian tidak wajar terjadi hampir di semua tempat di dunia. Kematian tidak wajar adalah kematian yang disebabkan oleh pembunuhan (homocide), bunuh diri (suicide), dan kecelakaan (accident) seperti cedera, kecelakaan lalu lintas, tenggelam, keracunan, dan kekerasan lainnya. Dapat diartikan bahwa kematian tidak wajar tidak terjadi karena penyakit proses penuaan normal. ${ }^{1-4}$

Menurut Malik, pembunuhan dibagi menjadi 2 (dua), yaitu pembunuhan sengaja dan pembunuhan kesalahan. Pembunuhan 
sengaja adalah suatu perbuatan dengan maksud menganiaya dan mengakibatkan hilangnya nyawa atau jiwa orang yang dianiaya, baik penganiayaan itu dimaksudkan untuk membunuh atau tidak dimaksudkan membunuh. Berbeda halnya dengan pembunuhan kesalahan, yaitu suatu perbuatan yang mengakibatkan kematian yang tidak disertai niat penganiayaan. ${ }^{5}$

Secara umum, bunuh diri berasal dari bahasa latin, yaitu "suicidium", dengan "sui" yang berarti sendiri dan "cidium" yang berarti pembunuhan. Schneidman mendefinisikan bunuh diri sebagai sebuah perilaku pemusnahan secara sadar yang ditujukan pada diri sendiri oleh seorang individu yang memandang bunuh diri sebagai solusi terbaik dari sebuah isu. Kecelakaan adalah serangkaian peristiwa dari kejadian yang tidak diduga sebelumnya, dan selalu mengakibatkan kerusakan benda, luka, atau kematian. ${ }^{5}$

Pada setiap kasus kematian tidak wajar yang diduga karena tindak pidana maka penyidik harus mengajukan permintaan visum et repertum/keterangan ahli. Visum et repertum merupakan keterangan yang dibuat oleh dokter atas permintaan penyidik yang berwenang mengenai hasil pemeriksaan medik terhadap manusia, baik hidup atau mati, ataupun bagian atau diduga bagian dari tubuh manusia, berdasarkan keilmuannya dan di bawah sumpah, untuk kepentingan peradilan. Visum et repertum merupakan salah satu alat bukti yang sah sebagaimana tertulis dalam pasal 184 KUHAP. Visum et repertum menguraikan segala sesuatu tentang hasil pemeriksaan medik yang tertuang di dalam bagian pemberitaan, yang karenanya dapat dianggap sebagai pengganti benda bukti. ${ }^{6}$ Kematian seseorang yang diduga tidak wajar, perlu dicari tahu penyebab kematiannya. Pihak yang paling berwenang menyatakan penyebab kematian seseorang ialah dokter forensik. ${ }^{1}$ Informasi penyebab kematian sangat diperlukan untuk kepentingan medikolegal dan keperluan asuransi terkait warisan. ${ }^{7}$

Sebab kematian lebih mengarah kepada alat atau sarana yang dipakai untuk mematikan korban sehingga sebab kematian jangan disalah artikan dengan mekanisme kematian yang lebih menjelaskan bagaimana korban mati setelah penyebab kematian terjadi. Untuk mengetahui secara pasti penyebab kematian perlu dilakukan bedah jenazah (autopsi). ${ }^{6,8}$

Kasus kematian tidak wajar di Sulawesi Utara sudah banyak terjadi; salah satunya yang terjadi di Desa Liningaan, Kecamatan Amurang, Kabupaten Minahasa Selatan ditemukan kerangka manusia dan hasil autopsi tim dokter forensik, korban diduga meninggal akibat pembunuhan karena ditemukan adanya keretakan di tulang dada akibat benturan benda tumpul yang menjadi sebab kematian dari korban. ${ }^{9}$

Di Indonesia sendiri kasus kematian tidak wajar seperti pembunuhan, bunuh diri, dan kecelakaan tidak jarang terjadi, namun penelitian yang dilakukan masih sangat jarang. Berdasarkan latar belakang ini maka peneliti tertarik untuk mengetahui gambaran sebab kematian pada kasus kematian tidak wajar yang diautopsi di RS Bhayangkara Manado dan RSUP Prof. Dr. R. D. Kandou Manado.

\section{METODE PENELITIAN}

Penelitian ini menggunakan data yang diambil di RS Bhayangkara Tingkat III Manado dan RSUP Prof. Dr. R. D. Kandou Manado. Jenis penelitian ialah deskriptif retrospektif. Subjek penelitian ialah seluruh data kasus kematian tidak wajar dalam Visum et Repertum yang diautopsi di RS Bhayangkara dan RSUP Prof. Dr. R. D. Kandou Manado tahun 2017-2018. Variabel penelitian ini ialah jumlah kasus kematian tidak wajar yang diautopsi, usia, jenis kelamin, dan sebab kematian.

Penelitian ini telah mendapat persetujuan dari Komisi Etik Penelitian Kesehatan RSUP Prof. Dr. R. D. Kandou Manado, dengan nomor keterangan layak etik yaitu No. 072/EC/KEPK-KANDOU/XI/2019.

\section{HASIL PENELITIAN}

Berdasarkan data yang diambil di RS Bhayangkara Tingkat III dan RSUP Prof. Dr. R. D. Kandou Manado, jumlah kasus 
kematian tidak wajar yang diautopsi pada tahun 2017-2018 sebanyak 77 kasus. Jumlah kasus pada tahun 2017 sebanyak 45 kasus (58\%) sedangkan pada tahun 2018 sebanyak 32 kasus (42\%). Berdasarkan data jenis kelamin, didapatkan 68 kasus ekshumasi ialah jenazah laki-laki dan 9 kasus kematian tidak wajar yang diautopsi ialah jenazah perempuan.

Tabel 1 memperlihatkan distribusi usia dari kasus kematian tidak wajar. Usia terbanyak ialah pada masa remaja akhir 1725 tahun dengan jumlah 18 kasus.

Tabel 1. Jumlah kasus kematian tidak wajar berdasarkan usia

\begin{tabular}{cc}
\hline Usia & $\begin{array}{c}\text { Jumlah } \\
\text { kasus }\end{array}$ \\
\hline Masa balita 0-5 tahun & 1 \\
Masa kanak-kanak 5-11 tahun & 2 \\
Masa remaja awal 12-16 tahun & - \\
Masa remaja akhir 17-25 tahun & 18 \\
Masa dewasa awal 26-35 tahun & 16 \\
Masa dewasa akhir 36-45 tahun & 16 \\
Masa lansia awal 46-55 tahun & 11 \\
Masa lansia akhir 56-65 tahun & 5 \\
Masa manula >65 tahun & - \\
\hline
\end{tabular}

Tabel 2 memperlihatkan distribusi sebab kematian pada kasus kematian tidak wajar yang diautopsi. Sebab kematian terbanyak ialah kekerasan tajam sebanyak 45 kasus.

Tabel 2. Kasus kematian tidak wajar berdasarkan sebab kematian

\begin{tabular}{cc}
\hline Sebab kematian & Jumlah kasus \\
\hline Kekerasan tajam & 45 \\
Kekerasan tumpul & 11 \\
Luka tusuk & 5 \\
Pencekikan & 3 \\
Perdarahan & 3 \\
Luka bakar & 2 \\
Keracunan CO & 2 \\
Tergantung & 2 \\
Luka bacok & 1 \\
Tenggelam & 1 \\
Kekerasan senjata api & 1 \\
Luka & 1 \\
\hline
\end{tabular}

\section{BAHASAN}

Hasil penelitian mendapatkan jumlah kasus kematian tidak wajar yang diautopsi di RS Bhayangkara Manado dan RSUP Prof. Dr. R. D. Kandou Manado tahun 2017-2018 sebanyak 77 kasus. Pada tahun 2017 terdapat 45 kasus (58\%) kematian tidak wajar yang diautopsi, kemudian pada tahun 2018 mengalami penurunan jumlah kasus sebanyak 32 kasus (42\%).

Jumlah kematian tidak wajar yang diautopsi di RS Bhayangkara Manado ialah 30 kasus (39\%) sedangkan jumlah kematian tidak wajar yang diautopsi di RSUP Prof Dr. R. D. Kandou Manado ialah 47 kasus (61\%). Dengan demikian jumlah kasus kematian tidak wajar yang diautopsi di RSUP Prof Dr. R. D. Kandou Manado lebih banyak dari RS Bhayangkara Manado. Pada penelitian sebelumnya yang dilakukan di RSUP Prof Dr. R. D. Kandou Manado. ${ }^{5}$ dan dari 77 Surat Visum et Repertum, kesemuanya dilakukan pemeriksaan autopsi sehingga dapat dilihat penyidik/pihak kepolisian memiliki penanganan yang baik dalam menangani kasus kasus kematian tidak wajar tersebut dan adanya kesadaran masyarakat dalam melaporkan kasus kematian tidak wajar kepada penyidik yang perlu dilakukan autopsi.

Kasus kematian tidak wajar yang diautopsi berdasarkan jenis kelamin yaitu jenazah laki-laki sebanyak 68 orang $(88 \%)$ dan jenazah perempuan sebanyak 9 orang (12\%). Hasil penelitian ini sejalan dengan penelitian di Turki dan Finlandia yang melaporkan sebagian besar kematian tidak wajar lebih banyak terjadi pada laki-laki dibandingkan perempuan karena sifat laki-laki yang lebih agresif, perilaku impulsif, dan banyak melakukan kegiatan di luar ruangan seperti berenang, mengendarai sepeda motor, dan lain-lain. ${ }^{10}$

Kasus kematian tidak wajar yang diautopsi berdasarkan usia mendapatkan bahwa usia 17-25 tahun (masa remaja akhir) ialah usia terbanyak yaitu 18 kasus. Hal ini dapat disebabkan oleh perselisihan dalam keluarga yang menjadi alasan bunuh diri dan pembunuhan di kalangan kaum muda. Kekerasan dalam keluarga berkon- 
tribusi besar dalam meningkatkan tingkat kejahatan di seluruh dunia. ${ }^{11}$ Sebuah penelitian di India dan National Institute of Mental Health and Neurosciences (NIMHAN) mengamati bahwa kelompok usia 15-18 tahun rentan untuk melakukan bunuh diri dan menggunakan kendaraan untuk bepergian sehingga rentan juga terhadap kecelakaan lalu lintas jalan. ${ }^{10}$ Dari 77 kasus kematian tidak wajar yang diautopsi pada tahun 2017-2018 didapatkan 69 kasus dengan usia jenazah diketahui dan 8 kasus dengan usia jenazah tidak diketahui. Selain itu, 1 kasus pada usia bayi cukup bulan. Penelitian di Sri Lanka menyatakan bahwa kematian jenazah lanjut usia (masa lansia awal 46-55 tahun dan masa lansia akhir 56-65 tahun) disebabkan karena memiliki tubuh yang lemah dan di samping itu lanjut usia memiliki banyak kondisi penyakit alami yang dapat menyebabkan kematian akibat trauma ringan. ${ }^{11}$

Kasus kematian tidak wajar yang dilakukan autopsi berdasarkan sebab kematian terbanyak ialah kekerasan tajam pada bagian kepala yang menyebabkan kerusakan jaringan otak sebanyak 45 kasus (58\%) diikuti oleh kekerasan tumpul pada urutan kedua terbanyak. Penelitian di sebuah Rumah Sakit di Pakistan menunjukkan penyebab kematian terbanyak ialah akibat kekerasan senjata api, karena banyaknya senjata api ilegal yang merajalela di kalangan masyarakat. ${ }^{12}$ Senjata api menjadi senjata pilihan karena seseorang dapat melakukan pembunuhan tanpa kontak fisik antara korban dan pelaku dan juga pelaku memiliki kesempatan untuk melarikan diri dari tempat kejadian perkara (TKP) dengan mudah. ${ }^{13}$

Hasil penelitian ini mendapatkan sebab kematian karena kekerasan senjata api hanya pada 1 kasus. Hal ini dapat disebabkan karena masih kurang beredarnya senjata api di kalangan masyarakat. Biasanya senjata api hanya ditemukan pada anggota Polisi atau Tentara maupun pemburu hewan. Selain itu, luka bakar ditemukan sebanyak 2 kasus pada jenazah perempuan berusia 7 tahun dan laki-laki muda. Penelitian yang dilakukan oleh ElMenya et $\mathrm{al}^{10}$ mengungkapkan bahwa negara-negara berpenghasilan rendah dan menengah mewakili sebagian besar kematian akibat luka bakar, termasuk luka bakar karena kecelakaan, pembunuhan, dan bunuh diri. Tinjauan tersebut juga menunjukkan bahwa perempuan dan anak kecil berisiko lebih besar mengalami luka bakar rumah tangga. Lebih lanjut, banyak penelitian juga melaporkan bahwa jenis kelamin perempuan berisiko tinggi meninggal akibat luka bakar. ${ }^{10}$ Hal ini dapat dikaitkan dengan penggunaan kayu bakar dan minyak tanah atau kompor gas yang digunakan untuk memasak, sedangkan pada anak kecil biasanya karena sulit untuk melarikan diri bila terjebak dalam sebuah ruangan yang terbakar atau bermain dengan korek api.

Penelitian oleh Kitulwatte et $\mathrm{al}^{11}$ di sebuah Rumah Sakit di Sri Lanka mengungkapkan bahwa terdapat sejumlah besar metode mematikan segera seperti menggantung, tenggelam, dan tercekik yang digunakan oleh para korban untuk melakukan bunuh diri. Di Eropa, metode bunuh diri yang paling sering dilakukan di antara kedua jenis kelamin ialah menggantung diri; namun, secara bermakna lebih tinggi pada laki-laki dibandingkan perempuan. ${ }^{10}$

\section{SIMPULAN}

Kasus kematian tidak wajar yang diautopsi terbanyak didapatkan pada tahun 2017, dengan jenis kelamin jenazah lakilaki, berusia 17-25 tahun (masa remaja akhir), dan sebab kematian kekerasan tajam. Secara keseluruhan dapat diketahui gambaran sebab kematian pada kasus kematian tidak wajar yang diautopsi di RS Bhayangkara Tingkat III Manado dan RSUP Prof. Dr. R. D. Kandou Manado tahun 2017-2018.

Penelitian tentang kasus kematian tidak wajar masih sangat jarang. Oleh karena itu diperlukan penelitian tahunan untuk mengetahui angka kematian tidak wajar di setiap provinsi dengan kerja sama antara Rumah Sakit, Dinas Kesehatan, Pihak Kepolisian Daerah, dan Badan Pusat 
Statistik tiap daerah. Data dari setiap daerah dilaporkan ke Pemerintah Pusat kemudian digabungkan menjadi data nasional dengan kerja sama Kementerian Kesehatan, Pihak Kepolisian, dan Badan Pusat Statistik.

\section{Konflik Kepentingan}

Penulis menyatakan tidak terdapat konflik kepentingan dalam studi ini.

\section{DAFTAR PUSTAKA}

1. Rahim M, Das TC. Mortuary profile for unnatural deaths at Forensic Medicine Department of Dhaka Medical College. Bangladesh Medical Journal. 1996; 38(2):48-51.

2. Dinas Kedokteran dan Kesehatan Polri. Buku Pegangan Ilmu Kedokteran Forensik (4th ed). Jakarta: Lembaga Kedokteran Kepolisian Unit Kedokteran Forensik,1996

3. Debata PK, Deswal S, Kumath M. Causes of unnatural deaths among children and adolescents in Northern India - A qualitative analysis of postmortem data. J Forensic Leg Med. 2014;26(2014): 53-5.

4. Ijomone EA, Uchendu OJ, Nwachokor NK. Pattern of unnatural death among females in Niger Delta: A retrospective medicolegal study. Annals of Tropical Pathology. 2019;10(1):6-10.

5. Langie YN, Tomuka D, Kristanto EG. Peran Visum et repertum dalam penegakan hukum pidana pada kasus kematian tidak wajar di Kota Manado. Jurnal Biomedik (JBM). 2015;7(1):48-53

6. Bhaskara DSM, Mallo JF, Tomuka D. Hasil autopsi sebab kematian mendadak tak terduga di Bagian Forensik BLU RSUP
Prof. Dr. R. D. Kandou Manado tahun 2010-2012. e-CliniC. 2014;2(1):3-8.

7. Henky. Gambaran pengisian kolom penyebab kematian pada sertifikat penyebab kematian di RSUP Sanglah Denpasar. Medicina (B Aires). 2018;49(3):372-5.

8. Idries AM, Tjiptomartono AL. Penerapan Ilmu Kedokteran Forensik dalam Proses Penyelidikan (edisi revisi). Jakarta: Sagung Seto, 2008; p.48-50, 204 -6.

9. Tribunnews.com. Kerangka yang ditemukan di Liningaan Minsel ternyata seorang mahasiswa. 1 November 2015 [cited 2019 Oct 22]. Available form: https://manado.tribunnews.com/2015/1 1/01/kerangka-yang-ditemukan-diliningaan-minsel-ternyata-seorangmahasiswa

10. Athani P, Hugar BS, Harish S, Girishchandra YP. Pattern of unnatural deaths among children: An autopsy study. Med Leg J. 2017;85(2):90-2.

11. Kitulwatte IDG, Edirisinghe PAS, Pratheepa Mendis HKNL, Wijesinghe PR, fernando a, rishani aa, et al. study on the pattern of unnatural deaths of women brought for medico-legal autopsy. Sri Lanka Journal of Forensic Medicine, Science \& Law. 2017;8(1): 13-22.

12. Malik R, Chughtai BR, Khursheed R, Amanat M, Khan SP, Rizvi S, et al. Pattern of unnatural deaths -an audit of autopsies. Journal of Rawalpindi Medical College (JRMC); 2017;21(1): 97-99

13. Parveen $H$, Naeem M, Pal MI, Iqbal J, Hussain I. Unnatural deaths; pattern of unnatural deaths In Faisalabad. The Professional Medical Journal. 2018; 25(2):321-4. 